\title{
The Kansas Tax Experiment: The Matter of Legal Form of Organization
}

\author{
By Shi Qi and Don SchlagenhauF* \\ Draft: February, 2019 \\ Very Preliminary
}

Conservative politicians have advocated tax cuts for business as a way to foster faster growth. In 2012, the State of Kansas sought to boost economic growth by enhancing investment spending and thus employment with a sweeping business taxcut program. This program lowered the (state) tax rate on pass-through business income to zero. The Kansas Tax Experiment is widely viewed as a dismal failure, and a cautionary tale for all future tax cuts. In this paper, we carefully analyze this policy in terms of a dynamic stochastic occupational choice model with heterogeneous firms. The model explicitly allows firms to enter and exit as well as to allow firms to make a decision on their legal form of organization (LFO). This is important as the tax cut in Kansas targeted pass-through firms rather that C-corporate firms. Because firms of different legal forms face different tax obligations, the lowering of the tax rate for pass-through firms means lowering the personal income tax for this type of firm. C-corporate firms may switch their LFO to take advantage of this favorable tax treatment. The Kansas tax policy distort firms LFO impacting the allocation of capital among firms. The model calibrated to the Kansas economic environment using data obtained from the State of Kansas Department of Revenue. When the Kansas tax policy is studied, we find that the economy experiences sluggish growth in both output and employment, while government deficits sharply increase. This is the same result that Kansas experienced, and is explained by pass-through firms facing tighter capital constraints and a decline in capital formation. In contrast, a lower corporate income tax rate leads to an expansion in the $C$ corporate sector resulting an increase in output, consumption, and capital formation. Moderate job growth follows.

\footnotetext{
* Qi: Economics Department, College of William and Mary, P.O. Box 8795 Williamsburg, VA 23187, sqi01@wm.edu. Schlagenhauf: Federal Reserve Bank of St. Louis, St. Louis, MO 63102, don.e.schlagenhauf@stls.frb.org. The views expressed in this article are those of the authors and do not necessarily reflect the views of the Federal Reserve System, the Board of Governors, or the regional Federal Reserve Banks. Any errors are solely our own.
} 
In 2012, the State of Kansas sought to boost the economy by passing a sweeping tax-cut program. Intending to boost investment and raise employment, the state tax rate on pass-through business income was lowered to zero. However, the Kansas economy experienced slower growth comparing to its neighboring states in the ensuing years, while the state government faced severe fiscal crisis resulted from the tax revenue shortfalls. The Kansas Tax Experiment is widely reported as a dismal failure, and a cautionary tale for all future tax cuts. In this paper, we take a careful look of the Kansas Experiment by focusing the legal form of organization (LFO). We argue that the failure of the Kansas tax cut program is mainly due to its targeted type of legal forms.

In the United States, a firm chooses to be either a pass-through business or a $\mathrm{C}$ corporation. In 2011, 75 percent of firms were of the pass-through legal form, and they hired nearly half of all workers. Pass-through firms include sole proprietorships, partnerships, limited liability firms, and $\mathrm{S}$ corporations. Although many legal differences exist between the pass-through and the $\mathrm{C}$ corporation legal forms, our model focuses on the essential trade-off a firm must face when choosing an LFO. A disadvantage of a firm filing as a $\mathrm{C}$ corporation is that the firm is subject to double taxation. A C corporation must pay the corporate income tax on its corporate profits. If remaining profits are distributed to shareholders, these profits are subject to the personal income tax. On the other hand, if a firm files as a pass-through entity, all profits are passed through to the business owners, who are subject only to the personal income tax. The LFO choice also has implications for the access to capital. Pass-through entities are subject to legal restrictions on access to capital. Legally, a pass-through entity can have no more than 100 shareholders and no foreign, institutional, or corporate shareholders. This type of firm cannot issue preferred stock, which limits its ability to attract "deep-pocket" investors such as venture capitalists. Given these restrictions, pass-through businesses are more likely to be capital constrained compared with $\mathrm{C}$ corporations. In the paper, data are examined across industry sectors and firm-size classes to provide evidence that capital constraints indeed differ by LFO.

Because firms of the two legal forms face different tax treatments, a change in the relative business income tax rates can affect firm LFO choices. When the personal income tax on pass-through business income is lowered, business owner may seek favorable tax treatment by switching from $\mathrm{C}$ corporate to pass-through legal form. The Kansas tax cuts distort firm LFO choices, and can impact the allocation of capital among firms in the economy. Ideally, marginal products of capital should be equalized across all firms in the economy. The distortion in LFO choices can cause inefficiency by leaving some high marginal-return-to-capital firms without sufficient access to capital. In our model, entrepreneurs finance their operations either by using personal wealth or by accessing the 
external capital market. More-productive entrepreneurs, with small individual personal wealth, are more likely to be capital constrained without external capital. If these firms were to choose the pass-through legal form to avoid double taxation, their access to the external capital market would be restricted. The resulting capital misallocation would in turn impact overall employment in the economy. In contrast, a reduction in the corporate income tax rate could encourage a pass-through firm to become a C corporation. As a result of the change in LFO, this firm would have additional access to capital, allowing expansion of operations and hiring of additional workers.

To evaluate the impacts from a change in business income taxes, this paper develops a dynamic stochastic occupational choice model with heterogeneous agents, similar to that of Chen, Qi and Schlagenhauf (2018). Model dynamics are introduced in a manner similar to Hopenhayn and Rogerson (1993). Occupational choice is modeled akin to Lucas (1978), and agents in the economy are able to choose between being non-employed, a worker, or an entrepreneur. Our model framework shares similarities to other papers in the literature. For example, Buera, Kaboski and Shin (2011) adopt an occupational choice model with financial constraints to evaluate the distortion of financial frictions on the allocation of capital and entrepreneurial talent across production units and its adverse effect on productivity. ${ }^{1}$ This paper builds upon the aforementioned literature by introducing a firm's choice of legal forms of organization.

Our data were obtained directly from the Kansas Department of Revenue, which started tracking firms' legal form of organization in 2012. The data is organized by LFOs, industry sectors, and levels of business income earned in Kansas. In particular, the data report the total number of firms, the number of entry firms, and number of firms that switch LFOs in each category. Our data show that the personal income tax exemption largely encourages existing businesses to switch LFOs, rather than encouraging new firms to adopt the Pass-through legal form.

The model is calibrated to match key statistics from the data. Using the calibrated model, this paper quantitatively evaluates the impact that tax-cut policies would have on firm LFO choice, and aggregate implications for output, consumption, and capital utilization, as well as employment. A couple of tax policy experiments are conducted with respect to the corporate income tax rate and the personal income tax rate. When pass-through business income is exempted, our model largely replicates what happened in Kansas following the tax experiment. Namely, the economy experiences sluggish growth in both outputs and employments, while the government deficits increases

\footnotetext{
${ }^{1}$ There are many papers using the Lucas (1978) style occupational choice model to study productivity misallocation. For example, Erosa (2001) shows financial costs of raising capital affects entrepreneurial occupational choice and causes misallocation of financial assets. Guner, Ventura and Xu (2008) use a version of the Lucas (1978) model to study size-dependent policies and misallocation. Many other papers document the implications of credit market imperfection and productivity - for example, Amaral and Quintin (2010) and Caselli and Gennaioli (2013). See Restuccia and Rogerson (2013) for a more detailed overview.
} 
sharply. The main factor is that the capital constraint is becoming more severe on average, resulting in a decline in capital formation. In contrast, with a lower corporate income tax rate, the $\mathrm{C}$ corporation sector expands significantly. As a result, the economy experiences an increase in output, consumption, and capital formation, similar to the findings in Fehr et al. (2013). A reduction in the corporate income tax rate also leads to moderate job growth.

\section{Background}

In May 2012, the then Governor Sam Brownback signed into law the Kansas Senate Bill Substitute HB2117. The key provisions were to exempt pass-through business incomes from state individual income taxes. At the same time, the top marginal income tax rate was lowered from $6.45 \%$ to $4.9 \%$. The main motivation behind the legislation was to spur economic growth and increase hiring in the state. The administration projected the policy would add 100,000 private-sector jobs.

In the immediate aftermath, the state of Kansas experiences a large budget shortfall, and the state experiences a $\$ 700$ million loss in revenue for the first year the tax plan went into effect. Figure 1 shows the personal income tax receipts in Kansas compared to the neighboring states.

Figure 1. Personal Income Tax Receipts, Kansas vs. Neighboring States

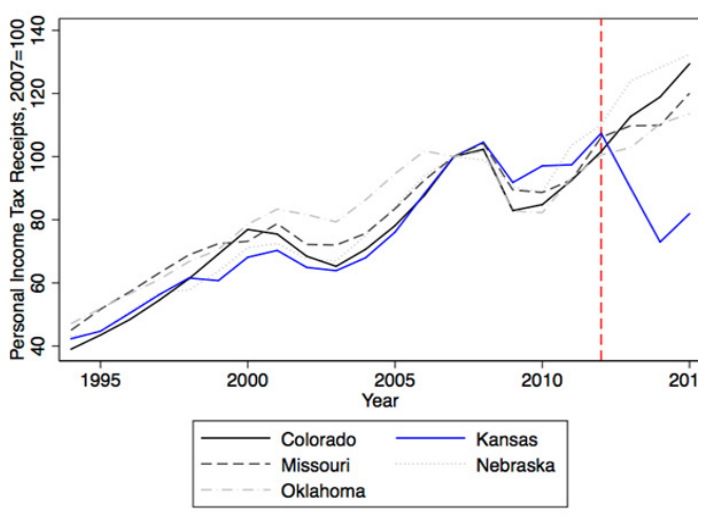

Firms in the State of Kansas are largely small businesses, as Table 1 shows. Overall, nearly 330,000 pass-through businesses, which was almost double the government projection of 191,000 entities, took advantage of the tax exemption targeting their legal forms. The tax policy did not change the overall size distribution of firms.

Interestingly, the tax exemption resulted in no discernible economic growth in the state. The employment growth in Kansas was stagnant compared to the U.S. average, as can be seen in Figure 2. By 2017, only 9,500 private-sector jobs were added, under-performing comparing to neighboring 
states like Missouri.

Table 1 - Fraction of Firms has $<$ 100K Kansas Income

\begin{tabular}{ccc}
\hline \hline Year & of Pass-Through & C Corporation \\
\hline 2012 & $84.6 \%$ & $91.2 \%$ \\
\hline 2013 & $84.6 \%$ & $91.0 \%$ \\
2014 & $83.9 \%$ & $90.8 \%$ \\
2015 & $84.4 \%$ & $90.9 \%$ \\
2016 & $84.5 \%$ & $92.6 \%$ \\
\hline \hline
\end{tabular}

Figure 2. Employment to Population Ration, 2010=1

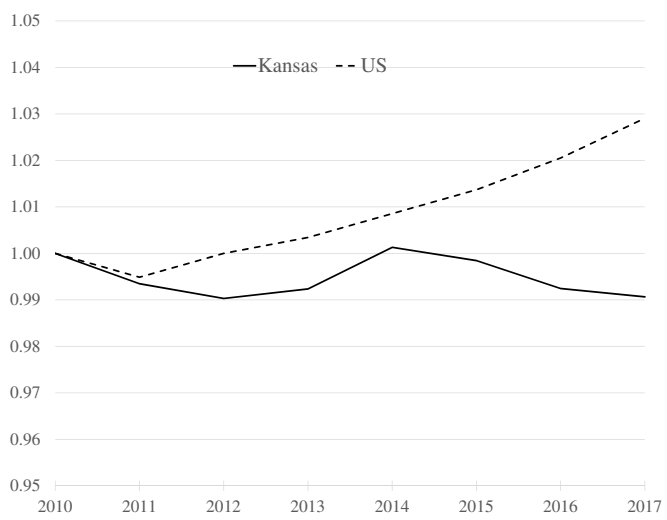

Meanwhile, the wage rate in the state was also declining. Table 2 shows the decline in employee compensation as a share of the state GDP in all private industries, except for Manufacturing and Retail Trade.

Table 2-Ratio of Employee Compensation to State GDP

\begin{tabular}{l|cc|cccc}
\hline \hline & 2011 & 2012 & 2013 & 2014 & 2015 & 2016 \\
\hline All Private Industries & 1.88 & 1.88 & 1.85 & 1.85 & 1.83 & 1.85 \\
\hline Construction & 4.73 & 3.55 & 3.68 & 3.51 & 3.98 & 4.97 \\
Manufacturing & 4.81 & 5.91 & 5.82 & 6.20 & 7.34 & 7.11 \\
Wholesale Trade & 7.42 & 7.16 & 5.67 & 5.88 & 6.16 & 6.17 \\
Retail Trade & 0.80 & 0.83 & 0.85 & 0.90 & 0.86 & 0.86 \\
Transportation & 2.06 & 2.05 & 2.07 & 1.99 & 2.10 & 2.19 \\
Finance and Real Estate & 1.90 & 1.93 & 2.34 & 2.26 & 1.53 & 1.37 \\
Administrative & 2.37 & 2.37 & 2.48 & 2.49 & 2.64 & 2.55 \\
Health Care & 1.21 & 1.17 & 1.11 & 1.06 & 0.96 & 0.99 \\
Accommodation & 0.39 & 0.41 & 0.41 & 0.45 & 0.45 & 0.46 \\
Other Services & 1.42 & 1.32 & 1.30 & 1.26 & 1.23 & 1.23 \\
\hline \hline
\end{tabular}

The tax policy sharply constrained state government spending. Overriding the governor's veto, the Kansas legislature voted for the Kansas Senate Bill 30, which repealed most of the provisions in HB2117 in 2017. 


\section{Data}

Our data was obtained directly from the Kansas Department of Revenue. The data tracks firms' legal form of organization from 2012 to 2016. Fiscal Year 2012 was the first year that the state of Kansas started tracking firms who switch legal forms. The data is organized by LFOs, industry sectors, and levels of business income earned in Kansas. In particular, the data report the total number of firms, the number of entry firms, and number of firms that switch LFOs in each category.

Table 3 summarizes the data over the years. After the tax policy change in 2012, there was a marked increase in rate of switching from $\mathrm{C}$ corporations to Pass-through entities, and a decline in entry rate of $\mathrm{C}$ corporations. Overall, the share of Pass-through firms was increasing in Kansas.

Table 3-Data Summary

\begin{tabular}{l|c|cccc}
\hline \hline & 2012 & 2013 & 2014 & 2015 & 2016 \\
\hline Number of P & 67,491 & 69,529 & 71,454 & 73,456 & 72,644 \\
Number of C & 15,870 & 15,961 & 16,069 & 16,221 & 14,917 \\
Total Number of Firms & 83,361 & 85,490 & 87,523 & 89,677 & 87,561 \\
\hline Fraction of P & $81.0 \%$ & $81.3 \%$ & $81.6 \%$ & $81.9 \%$ & $83.0 \%$ \\
\hline P Switch to C & $0.04 \%$ & $0.06 \%$ & $0.04 \%$ & $0.05 \%$ & $0.04 \%$ \\
C Switch to P & $0.18 \%$ & $0.38 \%$ & $0.23 \%$ & $0.19 \%$ & $0.22 \%$ \\
\hline Fraction of New P & $9.54 \%$ & $9.42 \%$ & $9.36 \%$ & $9.42 \%$ & $8.24 \%$ \\
Fraction of New C & $1.44 \%$ & $1.35 \%$ & $1.38 \%$ & $1.50 \%$ & $1.24 \%$ \\
\hline \hline
\end{tabular}

Table 4 summarizes the switching between LFOs by industry sectors.

Table 4-Summary Statistics By Industry: Net Switch Rate from C to P

\begin{tabular}{l|c|c|cccc}
\hline \hline & 2012 & $2013-16$ Avg & 2013 & 2014 & 2015 & 2016 \\
\hline Construction & $0.22 \%$ & $\mathbf{0 . 3 6 \%}$ & $\mathbf{0 . 5 4 \%}$ & $0.25 \%$ & $0.25 \%$ & $\mathbf{0 . 4 1 \%}$ \\
Manufacturing & $0.26 \%$ & $\mathbf{0 . 3 2 \%}$ & $\mathbf{0 . 2 6 \%}$ & $0.41 \%$ & $0.29 \%$ & $0.33 \%$ \\
Wholesale Trade & $0.36 \%$ & $0.37 \%$ & $\mathbf{0 . 4 3 \%}$ & $0.53 \%$ & $0.18 \%$ & $0.36 \%$ \\
Retail Trade & $0.15 \%$ & $\mathbf{0 . 2 9 \%}$ & $\mathbf{0 . 4 1 \%}$ & $\mathbf{0 . 2 6 \%}$ & $\mathbf{0 . 2 1 \%}$ & $\mathbf{0 . 2 9 \%}$ \\
Transportation & $0.26 \%$ & $0.20 \%$ & $0.07 \%$ & $0.25 \%$ & $0.28 \%$ & $0.21 \%$ \\
Finance & $0.06 \%$ & $\mathbf{0 . 1 0 \%}$ & $\mathbf{0 . 2 1 \%}$ & $\mathbf{0 . 1 1 \%}$ & $0.06 \%$ & $0.02 \%$ \\
Real Estate & $0.03 \%$ & $\mathbf{0 . 0 8 \%}$ & $\mathbf{0 . 1 7 \%}$ & $\mathbf{0 . 0 6 \%}$ & $0.03 \%$ & $\mathbf{0 . 0 6 \%}$ \\
Professional & $0.23 \%$ & $0.19 \%$ & $\mathbf{0 . 3 6 \%}$ & $0.13 \%$ & $0.16 \%$ & $0.12 \%$ \\
Administrative & $0.27 \%$ & $0.27 \%$ & $\mathbf{0 . 4 8 \%}$ & $0.19 \%$ & $0.18 \%$ & $0.23 \%$ \\
Health Care & $0.10 \%$ & $\mathbf{0 . 3 8 \%}$ & $\mathbf{0 . 8 9 \%}$ & $\mathbf{0 . 3 7 \%}$ & $0.07 \%$ & $\mathbf{0 . 2 1 \%}$ \\
Accommodation & $0.09 \%$ & $\mathbf{0 . 1 6 \%}$ & $-0.06 \%$ & $\mathbf{0 . 2 6 \%}$ & $\mathbf{0 . 2 0 \%}$ & $\mathbf{0 . 2 3 \%}$ \\
Other Services & $0.21 \%$ & $0.22 \%$ & $\mathbf{0 . 3 3 \%}$ & $0.16 \%$ & $0.18 \%$ & $0.22 \%$ \\
\hline
\end{tabular}

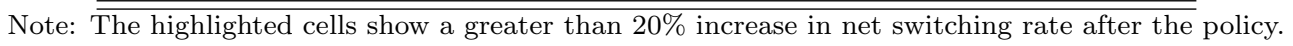

In particular, the net switching rate presented is the faction of firms switching from $\mathrm{C}$ corporations to Pass-through firms subtract the fraction of firms switching from Pass-through firms to $\mathrm{C}$ corporations. Both before and after the tax experiment, the net switching rate is positive for all the industries. For industries such as Retail, Real Estate, and Health Care, we see the net switching rate more than doubles after the tax policy. Most of the increase in switching happened 
immediately after the policy implementation in 2013.

Tables 5 and 6 show the fraction of entry Pass-through firms and $\mathrm{C}$ corporations, respectively, by industry. Interestingly, the entry rate of Pass-through firms changed very little post policy across different industries. The only exception was the Finance sector, which experienced an decline in the entry rate of Pass-through firms. Therefore, the income tax exemption to pass-through entities largely encourages existing businesses to switch LFOs, rather than encouraging new firms to adopt the Pass-through legal form. In contrast, there were declines in new firms adopting the $\mathrm{C}$ corporation legal form in several industry sectors. However, this is far from being universal across all industry sectors.

Table 5-Summary Statistics By Industry: Fraction of New P

\begin{tabular}{l|c|c|cccc}
\hline \hline & 2012 & $13-16 \mathrm{Avg}$ & 2013 & 2014 & 2015 & 2016 \\
\hline Construction & $8.89 \%$ & $8.87 \%$ & $9.30 \%$ & $9.10 \%$ & $9.07 \%$ & $8.00 \%$ \\
Manufacturing & $6.44 \%$ & $6.12 \%$ & $6.20 \%$ & $6.10 \%$ & $6.26 \%$ & $5.92 \%$ \\
Wholesale Trade & $7.30 \%$ & $6.76 \%$ & $7.56 \%$ & $6.81 \%$ & $6.53 \%$ & $6.16 \%$ \\
Retail Trade & $7.94 \%$ & $8.46 \%$ & $8.29 \%$ & $8.84 \%$ & $8.26 \%$ & $8.44 \%$ \\
Transportation & $8.74 \%$ & $8.66 \%$ & $8.61 \%$ & $8.84 \%$ & $8.99 \%$ & $8.19 \%$ \\
Finance & $15.07 \%$ & $\mathbf{1 1 . 6 6 \%}$ & $12.87 \%$ & $12.48 \%$ & $12.84 \%$ & $\mathbf{8 . 4 3 \%}$ \\
Real Estate & $9.05 \%$ & $9.12 \%$ & $9.35 \%$ & $9.15 \%$ & $9.41 \%$ & $8.57 \%$ \\
Professional & $10.15 \%$ & $9.47 \%$ & $10.03 \%$ & $9.96 \%$ & $9.68 \%$ & $8.23 \%$ \\
Administrative & $9.89 \%$ & $9.51 \%$ & $10.75 \%$ & $9.58 \%$ & $9.47 \%$ & $8.23 \%$ \\
Health Care & $8.24 \%$ & $7.95 \%$ & $7.63 \%$ & $7.75 \%$ & $8.61 \%$ & $7.80 \%$ \\
Accommodation & $10.78 \%$ & $11.09 \%$ & $10.80 \%$ & $11.17 \%$ & $11.83 \%$ & $10.56 \%$ \\
Other Services & $8.65 \%$ & $8.64 \%$ & $8.14 \%$ & $9.23 \%$ & $8.49 \%$ & $8.72 \%$ \\
\hline
\end{tabular}

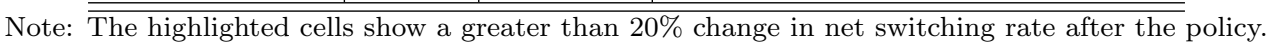

Table 6-Summary Statistics By Industry: Fraction of New C

\begin{tabular}{l|c|c|cccc}
\hline \hline & 2012 & $13-16 \mathrm{Avg}$ & 2013 & 2014 & 2015 & 2016 \\
\hline Construction & $1.22 \%$ & $0.98 \%$ & $\mathbf{0 . 9 4 \%}$ & $1.01 \%$ & $\mathbf{0 . 9 0 \%}$ & $1.07 \%$ \\
Manufacturing & $2.62 \%$ & $2.52 \%$ & $2.46 \%$ & $2.45 \%$ & $2.96 \%$ & $2.22 \%$ \\
Wholesale Trade & $2.16 \%$ & $2.40 \%$ & $2.70 \%$ & $2.55 \%$ & $1.96 \%$ & $2.41 \%$ \\
Retail Trade & $1.16 \%$ & $\mathbf{0 . 9 3 \%}$ & $\mathbf{0 . 8 5 \%}$ & $\mathbf{0 . 9 2 \%}$ & $1.02 \%$ & $\mathbf{0 . 9 2 \%}$ \\
Transportation & $1.58 \%$ & $1.49 \%$ & $1.56 \%$ & $1.36 \%$ & $1.69 \%$ & $1.36 \%$ \\
Finance & $2.56 \%$ & $2.24 \%$ & $2.07 \%$ & $2.41 \%$ & $2.61 \%$ & $\mathbf{1 . 8 8 \%}$ \\
Real Estate & $0.46 \%$ & $0.53 \%$ & $0.50 \%$ & $0.46 \%$ & $0.69 \%$ & $0.48 \%$ \\
Professional & $2.03 \%$ & $2.16 \%$ & $2.05 \%$ & $2.24 \%$ & $2.44 \%$ & $1.90 \%$ \\
Administrative & $2.17 \%$ & $1.87 \%$ & $2.00 \%$ & $1.92 \%$ & $1.87 \%$ & $\mathbf{1 . 6 9 \%}$ \\
Health Care & $1.17 \%$ & $1.00 \%$ & $\mathbf{0 . 8 9 \%}$ & $1.18 \%$ & $1.05 \%$ & $\mathbf{0 . 8 8 \%}$ \\
Accommodation & $1.30 \%$ & $1.41 \%$ & $1.76 \%$ & $1.24 \%$ & $1.31 \%$ & $1.32 \%$ \\
Other Services & $1.45 \%$ & $\mathbf{1 . 1 6 \%}$ & $1.25 \%$ & $\mathbf{1 . 1 0 \%}$ & $1.16 \%$ & $\mathbf{1 . 1 4 \%}$ \\
\hline
\end{tabular}

Note: $\overline{\overline{\text { The highlighted cells show a greater than } 20 \% \text { change in net switching rate after the }}}$ policy. 
Table 7 summarizes the switching between LFOs by business income earned in Kansas. Across all income categories, the net switching rate spiked immediately after the policy implementation in 2013.

Table 7 - Summary Statistics By Business Income: Net Switch Rate from C to P

\begin{tabular}{l|c|c|cccc}
\hline \hline & 2012 & $2013-16$ Avg & 2013 & 2014 & 2015 & 2016 \\
\hline Under $\$ 25 \mathrm{~K}$ & $0.13 \%$ & $\mathbf{0 . 1 9 \%}$ & $\mathbf{0 . 2 7 \%}$ & $\mathbf{0 . 1 8 \%}$ & $0.15 \%$ & $\mathbf{0 . 1 7 \%}$ \\
$\$ 25 \mathrm{~K}-\$ 50 \mathrm{~K}$ & $0.17 \%$ & $0.15 \%$ & $\mathbf{0 . 3 3 \%}$ & $0.11 \%$ & $0.07 \%$ & $0.10 \%$ \\
$\$ 50 \mathrm{~K}-\$ 100 \mathrm{~K}$ & $0.11 \%$ & $\mathbf{0 . 1 8 \%}$ & $\mathbf{0 . 2 5 \%}$ & $0.14 \%$ & $0.13 \%$ & $\mathbf{0 . 2 2 \%}$ \\
$\$ 100 \mathrm{~K}-\$ 250 \mathrm{~K}$ & $0.25 \%$ & $0.25 \%$ & $\mathbf{0 . 4 6 \%}$ & $0.24 \%$ & $0.10 \%$ & $0.22 \%$ \\
$\$ 250 \mathrm{~K}-\$ 500 \mathrm{~K}$ & $0.21 \%$ & $\mathbf{0 . 5 4 \%}$ & $\mathbf{1 . 1 9 \%}$ & $\mathbf{0 . 4 7 \%}$ & $0.14 \%$ & $\mathbf{0 . 3 4 \%}$ \\
$\$ 500 \mathrm{~K}-\$ 1 \mathrm{M}$ & $0.36 \%$ & $\mathbf{0 . 4 6 \%}$ & $\mathbf{0 . 6 5 \%}$ & $\mathbf{0 . 5 1 \%}$ & $0.42 \%$ & $0.25 \%$ \\
\hline
\end{tabular}

Note: The highlighted cells show a greater than $20 \%$ change in net switching rate after the policy.

Tables 8 and 9 show the fraction of entry Pass-through firms and C corporations, respectively, by business income. We do not observe significant changes in entry rates across different income categories.

Table 8-Summary Statistics By Business Income: Fraction of New P

\begin{tabular}{l|c|c|cccc}
\hline \hline & 2012 & $13-16$ Avg & 2013 & 2014 & 2015 & 2016 \\
\hline Under $\$ 25 \mathrm{~K}$ & $11.00 \%$ & $10.54 \%$ & $10.84 \%$ & $10.83 \%$ & $10.89 \%$ & $9.59 \%$ \\
$\$ 25 \mathrm{~K}-\$ 50 \mathrm{~K}$ & $7.70 \%$ & $7.63 \%$ & $7.65 \%$ & $7.90 \%$ & $8.10 \%$ & $6.86 \%$ \\
$\$ 50 \mathrm{~K}-\$ 100 \mathrm{~K}$ & $5.89 \%$ & $6.25 \%$ & $6.15 \%$ & $6.26 \%$ & $6.67 \%$ & $5.90 \%$ \\
$\$ 100 \mathrm{~K}-\$ 250 \mathrm{~K}$ & $5.39 \%$ & $4.79 \%$ & $5.16 \%$ & $4.79 \%$ & $4.88 \%$ & $4.34 \%$ \\
$\$ 250 \mathrm{~K}-\$ 500 \mathrm{~K}$ & $3.63 \%$ & $3.91 \%$ & $4.37 \%$ & $4.70 \%$ & $3.31 \%$ & $3.26 \%$ \\
$\$ 500 \mathrm{~K}-\$ 1 \mathrm{M}$ & $3.65 \%$ & $2.95 \%$ & $3.25 \%$ & $2.86 \%$ & $3.70 \%$ & $1.97 \%$ \\
\hline \hline
\end{tabular}

Table 9-Summary Statistics By Business Income: Fraction of New C

\begin{tabular}{l|c|c|cccc}
\hline \hline & 2012 & $13-16$ Avg & 2013 & 2014 & 2015 & 2016 \\
\hline Under $\$ 25 \mathrm{~K}$ & $1.88 \%$ & $1.81 \%$ & $1.77 \%$ & $1.86 \%$ & $1.97 \%$ & $1.64 \%$ \\
$\$ 25 \mathrm{~K}-\$ 50 \mathrm{~K}$ & $0.59 \%$ & $0.53 \%$ & $0.49 \%$ & $0.41 \%$ & $0.65 \%$ & $0.58 \%$ \\
$\$ 50 \mathrm{~K}-\$ 100 \mathrm{~K}$ & $0.42 \%$ & $0.31 \%$ & $0.30 \%$ & $0.24 \%$ & $0.33 \%$ & $0.36 \%$ \\
$\$ 100 \mathrm{~K}-\$ 250 \mathrm{~K}$ & $0.22 \%$ & $0.29 \%$ & $0.28 \%$ & $0.19 \%$ & $0.43 \%$ & $0.26 \%$ \\
$\$ 250 \mathrm{~K}-\$ 500 \mathrm{~K}$ & $0.12 \%$ & $0.19 \%$ & $0.16 \%$ & $0.22 \%$ & $0.17 \%$ & $0.20 \%$ \\
$\$ 500 \mathrm{~K}-\$ 1 \mathrm{M}$ & $0.29 \%$ & $0.35 \%$ & $0.29 \%$ & $0.38 \%$ & $0.54 \%$ & $0.18 \%$ \\
\hline \hline
\end{tabular}

\section{Model}

Agent preference $u(c, n, \iota)$ depends on current consumption level $c$, working hours $n$, and entrepreneurial choice $\iota$. In particular, we assume agents value consumption $c$, leisure $1-n$, and the opportunity to be an entrepreneur. The utility function takes the form

$$
u(c, n, \iota)=v(c, n)+\iota \cdot \eta
$$


Profit function. All entrepreneurs have the same Cobb-Douglas production function $F(z, k, l)=$ $z k^{\gamma} l^{\theta}$. Parameters $\gamma$ and $\theta$ are the capital and labor intensity parameters, respectively.

$$
\pi(z, k, l)=F(z, k, l)-(r+\delta) k-w l .
$$

Non-employed Agent:

$$
\begin{aligned}
W^{N}(z, a)= & \max _{c \geq 0, a^{\prime} \geq 0} u(c, 1,0)+\beta E_{z^{\prime} \mid z} V\left(z^{\prime}, a^{\prime}\right) \\
\text { subject to: } & c=(b+r a)-T^{p}(b+r a)+a-a^{\prime} .
\end{aligned}
$$

Employed Worker:

$$
\begin{aligned}
W^{E}(z, a)= & \max _{c \geq 0, a^{\prime} \geq 0} u(c, 1-\bar{n}, 0)+\beta E_{z^{\prime} \mid z} V\left(z^{\prime}, a^{\prime}\right) \\
\text { subject to: } & c=(w z \bar{n}+r a)-T^{p}(w z \bar{n}+r a)+a-a^{\prime} .
\end{aligned}
$$

Self-financing Pass-Through:

$$
\begin{array}{ll}
W^{P, \text { self }}(z, a)= & \max _{c \geq 0, a^{\prime} \geq 0, k \geq 0, l \geq 0} u(c, 1-\bar{n})+\beta E_{z^{\prime} \mid z} V\left(z^{\prime}, a^{\prime}\right) \\
\text { subject to: } & c=(\pi(z, k, l)+r a)-T^{p}(\pi(z, k, l)+r a)+a-a^{\prime} ; \\
& k \leq a .
\end{array}
$$

External-financing Pass-Through:

$$
\begin{array}{ll}
W^{P, e x t}(z, a)= & \max _{c \geq 0, a^{\prime} \geq 0, k \geq 0, l \geq 0} u(c, 1-\bar{n})+\beta E_{z^{\prime} \mid z} V\left(z^{\prime}, a^{\prime}\right) \\
\text { subject to: } & c=(\pi(z, k, l)+r a)-T^{p}(\pi(z, k, l)+r a)+a-a^{\prime} .
\end{array}
$$

Let $\lambda$ be the indicator whether an entrepreneur received and accepted external financing last period. If an agent has chosen $N$, or $W$, or chose to be an entreprenuer of either type, but didn't receive external financing offer, then $\lambda=0$. If an agent has chosen $P$, and received external financing last period, then $\lambda=1$. If an agent has chosen $C$, and received external financing last period, then $\lambda=2$. 
Ex-ante Pass-Through

$$
W^{P}(z, a, \lambda)=\left(1-\varphi^{p}(\lambda)\right) W^{P, s e l f}(z, a)+\varphi^{p}(\lambda) W^{P, e x t}(z, a) .
$$

where $\varphi^{p}(1)>\varphi^{p}(0)=\varphi^{p}(2)$. If received external financing last period, more likely to retain external financing this period.

C corporation:

$$
\begin{aligned}
W^{C, s e l f}(z, a) & =\max _{c \geq 0, a^{\prime} \geq 0, k \geq 0, l \geq 0} u(c, 1-\bar{n})+\beta E_{z^{\prime} \mid z} V\left(z^{\prime}, a^{\prime}\right) \\
\text { subject to: } c & =\left(\pi(z, k, l)-T^{c}(\pi(z, k, l))+r a\right)-T^{p}\left(\pi(z, k, l)-T^{c}(\pi(z, k, l))+r a\right)+a-a^{\prime} ; \\
k & \leq a .
\end{aligned}
$$

If a $\mathrm{C}$ corporation receives external financing, the value of the entrepreneur is

$$
\begin{aligned}
& W^{C, e x t}(z, a)=\max _{c \geq 0, a^{\prime} \geq 0, k \geq 0, l \geq 0} u(c, 1-\bar{n})+\beta E_{z^{\prime} \mid z} V\left(z^{\prime}, a^{\prime}\right) \\
& \text { subject to: } c=\left(\pi(z, k, l)-T^{c}(\pi(z, k, l))+r a\right)-T^{p}\left(\pi(z, k, l)-T^{c}(\pi(z, k, l))+r a\right)+a-a^{\prime} .
\end{aligned}
$$

Similarly, the ex-ante value function of a $\mathrm{C}$ corporation is

$$
W^{C}(z, a, \lambda)=\left(1-\varphi^{c}(\lambda)\right) W^{C, s e l f}(z, a)+\varphi^{c}(\lambda) W^{C, e x t}(z, a) .
$$

where $\varphi^{c}(2)>\varphi^{c}(0)=\varphi^{c}(1)$. If received external financing last period, more likely to retain external financing this period.

Value Function:

$$
V(z, a, \lambda)=\max \left\{W^{N}(z, a), W^{E}(z, a), W^{P}(z, a, \lambda), W^{C}(z, a, \lambda)\right\}
$$

Distribution. - Let $\mu(z, a, \lambda)$ denote the invariant cross-sectional distribution measure of agents with productivity $z$ and asset $a$ with external financing status $\lambda$. The evolution of this distribution depends on the endogenous asset choice $a^{\prime}(z, a, \lambda)$ and the exogenous Markov process of productivity $z$, as well as the transition matrix for $\lambda$.

If $\lambda=0, \lambda^{\prime}=1$ if $\chi(z, a, \lambda)=P$ with probability $\varphi^{P}(0)$ or if $\chi(z, a, \lambda)=C$ with probability $\varphi^{C}(0)$. 
If $\lambda=1, \lambda^{\prime}=1$ if $\chi(z, a, \lambda)=P$ with probability $\varphi^{P}(1)$ or if $\chi(z, a, \lambda)=C$ with probability $\varphi^{C}(1)$.

For any set of future asset levels $\mathcal{A}$ and any future productivity $z^{\prime}$, the following equation must be satisfied in the stationary equilibrium:

$$
\mu\left(z^{\prime}, \mathcal{A}, \lambda^{\prime}\right)=\int_{z, a, \lambda} 1_{\left\{a^{\prime}(z, a) \in \mathcal{A}\right\}} \sigma\left(\lambda^{\prime} \mid \lambda\right) \rho\left(z^{\prime} \mid z\right) \mu(d z, d a) .
$$

\section{A. Financial Intermediary}

A financial intermediary behaves competitively and earns zero profit. The behavior of the financial intermediary is fairly mechanical in our model. It extends external financing offers in a random and probabilistic fashion based on a firm's declared LFO. A pass-through business has a $\varphi^{p}$ chance of receiving an external financing offer, and a Corporation has a $\varphi^{c}$ chance of receiving an offer. Then as long as a firm accepts the external financing offer, the financial intermediary raises all needed capital. The model abstracts away from any financing costs. In equilibrium, the interest rate on savings $r$ adjusts until the capital market is cleared.

\section{B. Government}

The government collects revenue from a personal income tax and a corporate income tax. The personal income tax applies to all agents, including the non-employed, workers, and the two types of entrepreneurs. Labor, entrepreneurial, and interest incomes, as well as government transfers to the non-employed agents, are subject to the personal income tax, given by the tax function $T^{p}(y)$. The total personal income tax revenue is defined as

$$
\begin{aligned}
R^{p}= & \int_{z, a}\left[1_{\{\chi(z, a)=N\}} T^{p}(b+r a)+1_{\{\chi(z, a)=E\}} T^{p}(w z \bar{n}+r a)\right. \\
& +1_{\{\chi(z, a)=P\}}\left[\left(1-\varphi^{p}\right) T^{p}(\pi(z, a)+r a)+\varphi^{p} T^{p}\left(\pi^{*}(z)+r a\right)\right] \\
& \left.+1_{\{\chi(z, a)=C\}}\left[\left(1-\varphi^{c}\right) T^{p}\left(\pi(z, a)-T^{c}(\pi(z, a))+r a\right)+\varphi^{c} T^{p}\left(\pi^{*}(z)-T^{c}\left(\pi^{*}\right)+r a\right)\right]\right] \mu(d z, d a) .
\end{aligned}
$$

In the above equation, each indicator function $1_{\{\chi(z, a)\}}$ represents a particular occupational type $\chi(z, a)$ that is subject to either the personal or the corporate income tax. C corporate profits are subject to the corporate income tax $T^{c}(\pi)$, while profits from pass-through businesses are exempt. 
The total corporate income tax revenue is defined as

$$
R^{c}=\int_{z, a} 1_{\{\chi(z, a)=C\}}\left(\left(1-\varphi^{c}\right) T^{c}(\pi(z, a))+\varphi^{c} T^{c}\left(\pi^{*}(z)\right)\right) \mu(d z, d a) .
$$

The total revenue from the two sources is used to finance lump-sum transfers $b$ to the non-employed. The aggregate transfers $B$ is defined as

$$
B=\int_{z, a} 1_{\{\chi(z, a)=N\}} b \mu(d z, d a) .
$$

The government follows a balanced budget policy in equilibrium,

$$
B=R^{p}+R^{c}
$$

\section{Timing of Events}

The timing of events within a period proceeds as follows:

1) An agent enters a period with productivity $z$ and assets $a$.

2) The occupational decision $\chi$ is made.

3) The financial intermediary makes random external financing offers, and firms receive offers.

4) Production occurs. All agents receive their respective earnings.

5) The government levies taxes to finance transfers and exogenous government spending.

6) Consumption and saving decision are made.

7) Agents draw new productivity shocks, and the period ends.

\section{Labor Market}

The effective labor supply from an employed worker is his productivity $z$ times the hours worked $\bar{n}$. We aggregate over all employed workers to obtain the total labor supply,

$$
L^{S}=\int_{z, a} 1_{\{\chi(z, a)=E\}} z \bar{n} \mu(d z, d a) .
$$


Both pass-through firms and $\mathrm{C}$ corporations demand labor. Aggregating labor demand across entrepreneur types gives the measure of total labor demand,

$$
\begin{aligned}
L^{D}= & \int_{z, a}\left[1_{\{\chi(z, a)=P\}}\left(\left(1-\varphi^{p}\right) l(z, a)+\varphi^{p} l^{*}(z)\right)\right. \\
& \left.\quad+1_{\{\chi(z, a)=C\}}\left(\left(1-\varphi^{c}\right) l(z, a)+\varphi^{c} l^{*}(z)\right)\right] \mu(d z, d a) .
\end{aligned}
$$

In equilibrium, the wage $w$ clears the labor market, so

$$
L^{S}=L^{D}
$$

\section{E. Capital Market}

Capital supply in the market is the sum of all agents' assets, which is defined as

$$
K^{S}=\int_{z, a} a^{\prime}(z, a) \mu(d z, d a) .
$$

Both pass-through firms and C corporations demand capital. Aggregating capital demand across entrepreneurs under different organizational forms gives the total capital demand,

$$
\begin{aligned}
K^{D}= & \int_{z, a}\left[1_{\{\chi(z, a)=P\}}\left(\left(1-\varphi^{p}\right) k(z, a)+\varphi^{p} k^{*}(z)\right)\right. \\
& \left.+1_{\{\chi(z, a)=C\}}\left(\left(1-\varphi^{c}\right) k(z, a)+\varphi^{c} k^{*}(z)\right)\right] \mu(d z, d a) .
\end{aligned}
$$

In equilibrium, the interest rate $r$ clears the capital market, so

$$
K^{S}=K^{D}
$$

Given the model specified above, a stationary equilibrium is defined in a standard way. Appendix B outlines the algorithm for solving the model.

\section{F. Model Specification}

The model period is five years. The reason for using a five-year model is twofold. First, changes to a firm's LFO status can occur over a few years. For instance, when a C corporation converts 
to an $\mathrm{S}$ corporation, the firm could still pay $\mathrm{C}$ corporation taxes on some of its income (i.e., by selling appreciated assets). The Small Business Jobs Act of 2010 stipulates that the recognition period of status conversion is five years. Therefore, using five-year periods in the model is appropriate, as the model abstracts from these complex tax treatments during the conversion period. In addition, individual agents in the model make occupational decisions based on their current-period asset position and productivity draw. The model abstracts away from direct intertemporal dependency of occupational status. Hence, to avoid high-frequency temporary occupational changes, it is preferable in our calibration to use a five-year model period.

The logarithm of productivity $z$ follows an $\operatorname{AR}(1)$ process with autocorrelation $\varrho_{z}$ and standard deviation $\sigma_{z}$, or $\log \left(z^{\prime}\right)=\varrho_{z} \log (z)+\varepsilon$, where $\varepsilon \sim N\left(0, \sigma_{\varepsilon}^{2}\right)$. Numerically, the method developed in Tauchen (1986) is used to construct a first-order Markov process approximation.

Agent per-period utility is specified as

$$
u(c, n, \iota)=\alpha \log (c)+(1-\alpha) \log (1-n)+\iota \cdot \eta,
$$

where the relative importance of consumption to leisure is given by the parameter $\alpha .^{2}$

To allow for progressivity, the personal income tax function proposed by Gouveia and Strauss (1994) is employed. Given any income $m$, the total personal income tax is

$$
T^{p}(m)=a_{0}\left(m-\left(m^{-a_{1}}+a_{2}\right)^{-\frac{1}{a_{1}}}\right)
$$

where $\left(a_{0}, a_{1}, a_{2}\right)$ are parameters. Parameter $a_{0}$ is the limiting average tax rate when $m \rightarrow \infty$, and parameter $a_{1}$ captures progressivity. This functional form is adopted by recent papers on optimal taxation, such as Conesa and Krueger (2006) and Conesa, Kitao and Krueger (2009). Following the approach in these papers, we use parameter values of $a_{0}=0.258$ and $a_{1}=0.768$ from the original estimation of Gouveia and Strauss (1994). The parameter $a_{2}$ is chosen so that the government budget constraint is balanced in the equilibrium.

${ }^{2}$ This functional form is a special case of the following function

$$
u(c, n, \iota)=\frac{\left(c^{\alpha}(1-n)^{1-\alpha}\right)^{1-\xi}-1}{1-\xi}+\iota \cdot \eta,
$$

which is a constant-relative-risk-aversion (CRRA) transformation of the Cobb-Douglas utility function. This preference specification is consistent with balanced growth. One focus of this paper is the employment effect of the corporate income tax policy change. The employment effect is largely dependent upon agents' labor supply decisions, which is a function of real wages in the economy. In this preference specification, the relative share of working to leisure is constant with respect to wages, so the income effect of an increase in wages cancels out with the substitution effect. In the special case, the CRRA parameter $\xi$ is set to be 1. Calibration exercise with this more general form of utility function yields a CRRA parameter $\xi$ close to 1 , and gives similar qualitative results. 
The corporate income tax obligation is assumed to be proportional to profits, or $T^{c}(\pi)=\tau^{c} \cdot \pi$. A corporate income tax function could be estimated to take into account the progressivity in the U.S. corporate tax code. However, the legislative corporate tax rates are not applicable because of the myriad of corporate tax loopholes. To avoid dealing with issues of legislative versus effective corporate tax rates, the proportional tax assumption seems appropriate. The average effective corporate income tax rate $\tau^{c}$ is estimated and assumed to be the same for all $\mathrm{C}$ corporations.

\section{G. Independently Calibrated Parameters}

In the model, an agent is either non-employed with leisure being 1 or working full time with leisure being $1-\bar{n}$. We set $\bar{n}$ by assuming that individuals have 98 hours a week of substitutable time not spent eating, sleeping, or engaged in other personal care. If an agent spends 40 hours a week working full time, $\bar{n}$ approximately equals 0.4 . The calibration of $\bar{n}$ is similar to others' treatments in the literature, such as Hansen and Imrohoroglu (1992).

Table 10-Parameters Calibrated Independently

\begin{tabular}{|c|c|c|}
\hline Description & Parameter & Value \\
\hline \multicolumn{3}{|l|}{ From Data } \\
\hline Full-time Hours Worked & $\bar{n}$ & 0.40 \\
\hline Corporate Income Tax Rate & $\tau^{c}$ & 0.285 \\
\hline Depreciation Rate on Capital & $\delta$ & 0.082 \\
\hline Risk-free Interest Rate & $r$ & 0.040 \\
\hline \multicolumn{3}{|l|}{ From Gouveia and Strauss (1994) } \\
\hline Limiting Avg. Personal Income Tax Rate & $a_{0}$ & 0.258 \\
\hline Personal Income Tax Progressivity Parameter & $a_{1}$ & 0.768 \\
\hline \multicolumn{3}{|c|}{ From Chen, Qi, Schlagenhauf (2018) } \\
\hline Production Function Parameter on Capital & $\gamma$ & 0.241 \\
\hline Production Function Parameter on Labor & $\theta$ & 0.643 \\
\hline Productivity Persistence & $\varrho_{z}$ & 0.821 \\
\hline Standard Deviation of Productivity & $\sigma_{z}$ & 0.245 \\
\hline Cobb-Douglas Utility Parameter on Consumption & $\alpha$ & 0.501 \\
\hline Discount Rate & $\beta$ & 0.950 \\
\hline Non-employment Lump Sum Transfer & $b$ & 0.238 \\
\hline Entrepreneurial Non-pecuniary Benefit & $\eta$ & 0.305 \\
\hline
\end{tabular}

The corporate income tax rate $\tau^{c}$ is set to be the average effective tax rates from 2000-2010, which is calculated based on NIPA and the Corporation Complete Report from the IRS. Following similar definitions in Mertens and Ravn (2013), the average corporate income tax rate is the federal, state, and local taxes on corporate income (NIPA Table 3.1 line 5), excluding the tax on Federal Reserve Banks (NIPA Table 3.2 line 8), divided by the corporate income tax base; the corporate income tax base is the total income subject to tax from all active corporations, other than those filing forms 1120S, 1120-REIT, and 1120-RIC (IRS Complete Report Table 12 line 81). Based on our calculation, the average effective corporate income tax rate is 28.5 percent. 
The depreciation rate $\delta$ is the total depreciation of private fixed assets by corporate firms, partnerships, and sole proprietorships (NIPA Fixed Asset Table 6.4 lines 2, 6, and 7) divided by the total private fixed assets of corporate firms, partnerships, and sole proprietorships (NIPA Fixed Asset Table 6.1 lines 2, 6, and 7). The estimated annual depreciation rate is 8.2 percent. Hence, the five-year capital depreciation rate is 35 percent.

The rest of the independently calibrated parameters are from our paper, Chen, Qi and Schlagenhauf (2018). Table 10 summarizes the set of parameters that are independently calibrated.

\section{H. Calibration Results}

The remaining parameters in the model are calibrated jointly in the benchmark stationary equilibrium. These parameters and their calibrated values are summarized in Table 11.

Table 11 -Parameters Calibrated Jointly in Equilibrium

\begin{tabular}{lcc}
\hline \hline Description & Parameter & Value \\
\hline Pass-Through Initial External Financing Probability & $\varphi^{P}$ & 0.591 \\
C corporation Initial External Financing Probability & $\varphi^{C}$ & 0.907 \\
Entrepreneur Continuing External Financing Probability & $\varphi^{X}$ & 0.966 \\
\hline \hline
\end{tabular}

A set of empirical moments are carefully chosen to help pin down these parameters. These data moments discipline the model so as to capture certain significant economic aspects central to our policy experiments. A comparison of the data and model moments is presented in Table 12. The benchmark model fits the data well. In particular, the switching rates are on target.

Table 12-Data and Model Moments

\begin{tabular}{lcc}
\hline \hline Description & Data & Model \\
\hline Fraction of C Corporations & 0.249 & 0.221 \\
Entry Rate of Pass-Through Firms & 0.089 & 0.066 \\
Entry Rate of C Corporation & 0.022 & 0.023 \\
Switching Rate of $\mathrm{P} \Rightarrow \mathrm{C}$ & 0.001 & 0.001 \\
Switching Rate of C $\Rightarrow \mathrm{P}$ & 0.002 & 0.002 \\
\hline \hline
\end{tabular}

\section{Policy Experiment}

In this section, we use the benchmark model to study the aggregate impact of tax policy change. In the policy experiment, we hold interest rate fixed, while allowing wage rate to clear the labor market. The government is assumed to hold the same level of spending before and after the experiment, so deficit spending is allowed. In the first experiment, we mirror the Kansas tax 
experiment by allowing $10 \%$ fo the pass-through business income to be tax exempt. Here we are assuming that the Kansas state income tax bill is $10 \%$ of the overall income tax bills the passthrough business owners have to pay. In the second experiment, we cut the corporate income tax by $10 \%$ instead.

We first look at the government deficit. We assume that the government balance its budget in the benchmark economy. If the pass-through business income tax were exempt in Kansas, the state budget deficit is $2.5 \%$ of its output. If the corporate income tax was cut, the deficit is only $1.4 \%$, just over half of that under the pass-through tax cut.

We also look at firm dynamics (entry and switching rates), employment, and capital formation. Our result is presented in Table 13, which shows the percent changes from the benchmark economy.

Table 13-Policy Experiment: Changes From Benchmark

\begin{tabular}{lrr}
\hline \hline Description & $10 \%$ P-Tax & $10 \%$ C-Tax \\
\hline Fraction of C Corporations & $-20.8 \%$ & $15.9 \%$ \\
Entry Rate of Pass-Through Firms & $43.9 \%$ & $-26.5 \%$ \\
Entry Rate of C Corporation & $-8.7 \%$ & $60.9 \%$ \\
Switching Rate of P $\Rightarrow$ C & $6.7 \%$ & $133.3 \%$ \\
Switching Rate of C $\Rightarrow$ P & $50.0 \%$ & $-10.0 \%$ \\
\hline Wage Rate & $1.0 \%$ & $3.9 \%$ \\
Non-employment Rate & $-0.7 \%$ & $-2.6 \%$ \\
Output & $-2.0 \%$ & $10.0 \%$ \\
Capital Demand & $-2.2 \%$ & $10.0 \%$ \\
\hline \hline
\end{tabular}

In the top panel of Table 13, the sign of changes under a personal income exemption from passthrough businesses matches what happened in Kansas. There was a large increase in the switching rate from $\mathrm{C}$ corporation to Pass-through entities. The entry rate of $\mathrm{C}$ corporations declines slightly. The only exception we do not match is that our model predicts a large increase in Pass-through entry rate, but the data show little increase.

The consequences of these two alternative tax cuts on the economy are drastically different. Compared to a personal income exemption, a corporate income tax cut would generate four times the wage increase, four times of the non-employment rate decline. A personal income tax exemption would reduce both overall output and capital formation, while a corporate income tax cut does the opposite. In general, a personal income tax exemption exacerbate productivity misallocation by encouraging a significant fraction of the firms in the economy to adopt the legal form with more capital constraints. 


\section{Conclusion}

This paper develops a dynamic stochastic occupational choice model with heterogeneous agents and incorporates endogenous entrepreneurial decisions with respect to legal forms of organization. A calibrated model is employed to evaluate the impact of the Kansas tax experiment.

In the economy, the business income tax distorts firm entry decisions and generates dispersion in marginal returns to capital across existing firms due to different tightness of capital constraints. An important contribution of the paper is to point out the importance of considering LFO choice when evaluating the corporate income tax policy. In general, a personal income tax exemption exacerbate productivity misallocation by encouraging a significant fraction of the firms in the economy to adopt the legal form with more capital constraints.

\section{REFERENCES}

Amaral, Pedro S, and Erwan Quintin. 2010. "Limited Enforcement, Financial Intermediation, and Economic Development: a Quantitative Assessment." International Economic Review, 51(3): 785-811.

Buera, Francisco J, Joseph P Kaboski, and Yongseok Shin. 2011. "Finance and Development: A Tale of Two Sectors." The American Economic Review, 101(5): 1964-2002.

Caselli, Francesco, and Nicola Gennaioli. 2013. "Dynastic Management." Economic Inquiry, 51(1): 971-996.

Chen, Daphne, Shi Qi, and Don Schlagenhauf. 2018. "Corporate Income Tax, Legal Form of Organization, and Employment." American Economic Journal: Macroeconomics, 10(4): 270-304.

Conesa, Juan Carlos, and Dirk Krueger. 2006. "On the Optimal Progressivity of the Income Tax Code." Journal of Monetary Economics, 53(7): 1425-1450.

Conesa, Juan Carlos, Sagiri Kitao, and Dirk Krueger. 2009. "Taxing Capital? Not a Bad Idea After All!" The American Economic Review, 99(1): 25-48.

Erosa, Andrés. 2001. "Financial Intermediation and Occupational Choice in Development." Review of Economic Dynamics, 4(2): 303-334.

Fehr, Hans, Sabine Jokisch, Ashwin Kambhampati, and Laurence J Kotlikoff. 2013. "Simulating the Elimination of the US Corporate Income Tax." National Bureau of Economic Research. 
Gouveia, Miguel, and Robert P Strauss. 1994. "Effective Federal Individual Income Tax Functions: An Exploratory Empirical Analysis." National Tax Journal, 317-339.

Guner, Nezih, Gustavo Ventura, and Yi Xu. 2008. "Macroeconomic Implications of Sizedependent Policies." Review of Economic Dynamics, 11(4): 721-744.

Hansen, Gary D., and Ayse Imrohoroglu. 1992. "The Role of Unemployment Insurance in an Economy with Liquidity Constraints and Moral Hazard." Journal of Political Economy, 100(1): 118-142.

Hopenhayn, Hugo, and Richard Rogerson. 1993. "Job Turnover and Policy Evaluation: A General Equilibrium Analysis." Journal of Political Economy, 101(5): 915-38.

Lucas, Robert E. 1978. "On the Size Distribution of Business Firms." The Bell Journal of Economics, 9(2): 508-23.

Mertens, Karel, and Morten O. Ravn. 2013. "The Dynamic Effects of Personal and Corporate Income Tax Changes in the United States." The American Economic Review, 103(4): 1212-1247.

Restuccia, Diego, and Richard Rogerson. 2013. "Misallocation and Productivity." Review of Economic Dynamics, 16(1): 1-10.

Tauchen, George. 1986. "Finite State Markov-Chain Approximations to Univariate and Vector Autoregressions." Economics Letters, 20: 177-181. 